\title{
Of individuals and systems: The impact of personal and impersonal factors on learning
}

\author{
Stephen Roche
}

Published online: 25 February 2014

(C) Springer Science+Business Media Dordrecht and UNESCO Institute for Lifelong Learning 2014

Research indicates that non-school factors play as great if not a greater role than teaching or curriculum in a child's success at school, especially primary school (Berliner 2009). This means that home and family life very often outweighs what occurs in the classroom. Non-school factors include a family's socioeconomic status, parents' educational level, family integrity and immigrant status. This issue of the International Review of Education features two articles dealing with the influence of family factors on children's experience and success in primary school. A further article examines how gender impacts on the learning experience of female secondary students in Tunisia. The fourth article switches from the personal to a broader societal perspective, considering how structural racial inequalities have been redressed by South Africa's post-Apartheid adult education policies. The issue concludes with a more conceptual paper, an examination of how the theory and practice of systems thinking can help to make school leaders more effective.

Our first article looks (in French) at the influence of family status on primary school enrolment in Madagascar. As the authors - Valérie Delaunay, Bénédicte Gastineau and Frédérique Andriamaro - point out, Madagascar boasts one of the highest primary-school enrolment rates and one of the best records on gender parity in primary education in Africa, yet school dropout rates remain stubbornly high (UNESCO 2014). Using data from the 2009 Demographic and Health Survey (DHS) ${ }^{1}$ and taking into account the particularities of Malagasy social, gender and family norms (such as the widespread practice of fostering), the authors explore the influence of a child's family status on the likelihood of his/her remaining in school. Family status is defined in relation to residential settings and the status of parents in

\footnotetext{
1 The DHS studies, largely funded by the U.S. Agency for International Development (USAID), are conducted in more than 90 countries by ICF International.
}

S. Roche $(\square)$

UNESCO Institute for Lifelong Learning, Hamburg, Germany

e-mail: s.roche@unesco.org 
the household; for example, whether the child resides with his/her biological parents (and with one or both), whether or not their parents are heads of household, married, unmarried or divorced, or whether the child is in the care of grandparents or other relatives. The results reveal a more nuanced picture of social advantage and disadvantage than would be possible if relying on economic data such as family income alone. They confirm the protective benefit for children of living with their biological parents and reveal shifting patterns of disadvantage depending on a child's place within their household and the proximity of the biological parents.

Our next article also deals with family status, but in a very different context. China, the newest "workshop of the world", is experiencing a massive population shift from rural to urban areas. Roughly 155 million Chinese, almost 12 per cent of the population, are now migrants within their own country (Chan 2013). Such a large population movement has major consequences for education and learning, particularly of children. This study by Shuang Chen, Jennifer Adams, Zhiyong Qu, Xiaohua Wang and Li Chen is one of the first to investigate how parental migration affects children's experience and achievement in school. Using data collected in 2008 in the Haidian and Changping districts of Beijing and rural Henan and Shaanxi provinces, the authors compare the academic engagement levels of three groups of children: those who migrated with their parents and attend migrant schools; those who stayed behind in the care of other relatives; and those whose parents did not migrate. The advantage of using "academic engagement" rather than test scores or enrolment rates as a measure of student success is that the latter are very often precursors to enrolment or performance. The authors also explore how factors such as absence of parental support, poor teaching quality and pressures to engage in non-school activities disproportionately affect migrant children. Their findings show that the academic engagement of migrant children attending migrant schools is lower than that of rural children of non-migrant parents. The correlation between academic engagement and parental migration status can be accounted for in part by the support children receive from family and teachers. At the same time, the correlation between certain measures of family and school support and academic engagement also varies by parental migration status: for example, high teacher turnover rates significantly reduce migrant children's odds of liking schools, but do not affect children of non-migrant parents.

Nelson Mandela famously declared that "Education is the most powerful weapon we can use to change the world" (Mandela 2003). As the first democratically elected president of South Africa, Mandela had a unique opportunity to test that idea. In 1994, much hope was invested in the potential of education and training to redress structural racial inequalities. In a wide-ranging study, Zelda Groener looks at the opportunities grasped and missed by post-Apartheid governments to raise the economic and social status of South African adults through training and education, and at the challenges and obstacles (including international pressures) they faced in the process. She reviews the relevant literature related to domestic and international developments (especially the dominance of neo-liberal economic models in the post-Apartheid years) and skills development policies in South Africa and draws attention to the structure of the shrinking post-Apartheid capitalist economy, which favours skilled labour over low-skilled labour and thus reproduces structural racial 
inequalities. Because, the author argues, racial inequality was etched into all political and economic structures under Apartheid, the barriers to skills development and economic opportunity experienced by Black South Africans are also structural, and structural transformation of the entire South African economy is therefore needed to redress these inequalities. She identifies five structural and pedagogical barriers as likely causes for low completion rates of skills development courses and concludes with a brief discussion of the debates about structural reform which could create political and economic conditions facilitating a change in the lives of Black, low-skilled and unemployed adults and youth.

It is probably no accident that the 2011 Arab Spring began in Tunisia. According to UNESCO's most recent Global Monitoring Report, "a major educational expansion over the last 30 years has given rise to strong democratic aspirations" (UNESCO 2014, p. 171). Tunisia also has an impressive record in gender equality in education, with a Gender Parity Index (GPI) of 0.99 in 2011 for access to primary education (ibid., p. 340). But, of course, statistics never tell the full story. In their study of how language is used in physical and sports education in Tunisia, Makram Zghibi, Hajer Sahli, Mohamed Jabri, Samira Ouelhezi, Noomen Guelmemi and Nathalie Wallian examine (in French) the role of gender in how students learn and interact, and how the presence of a teacher influences this communication. They conducted a statistical analysis on two samples (one with a teacher present, one without), and separated the results by student gender. They then compared the data averages of the two samples using the Mann-Whitney test. ${ }^{2}$ They justify their decision to focus on sports education with the argument that sport "is a process where the social construction of masculinity and femininity plays a very significant role" and that sports act as "an ideal platform to communicate gender roles free of socially constructed gender differences" [le sport représente un processus où la construction sociale de la masculinité et de la féminité joue un rôle fort significant. Les activités sportives agissent comme une plateforme idéale pour diffuser les rôles des hommes et des femmes et des constructions qui ne font pas exception au marquage sexuel]. In a more philosophical discussion, the authors consider how processes of exchange and confrontation within a group of learners contribute to the emergence of new cognitive behaviours and support the social learning necessary for the pursuit of common goals. The study found that students are more grouporiented and listen to one another more in the presence of a teacher, and that girls experience a disproportionate disadvantage in sports and physical education. The authors nonetheless recommend that institutions mix boys and girls in sports.

Readers of this journal will be familiar with the risks of excessive specialisation. Where the natural sciences led, the social sciences have followed, often with a zeal to outdo "hard" scientists in analytical rigour. The field of comparative education was born from the desire to broaden perspectives and open up new horizons. Yet, here too there is a tendency to focus the gaze too narrowly, and to devise solutions based on ever more detailed analysis of specific problems. In the last fifty years an alternative approach has gained ground, emerging from the somewhat unlikely

\footnotetext{
2 The Mann-Whitney test is a nonparametric test that allows two groups or conditions or treatments to be compared without making the assumption that values are normally distributed.
} 
fields of engineering and computer science: systems thinking (ST). Whereas traditional analysis focuses on separation of discrete elements (analysis being, literally, the antonym of synthesis), systems thinking looks at how the object of study interacts with the larger system of which it is part. Since no man is an island, and nothing exists in a vacuum, this approach can be applied to anything. The authors of our final article, Haim Shaked and Chen Schechter, discuss how systems thinking may be applied to school leadership, claiming that it may enable school principals to develop highly performing schools which are able to cope successfully with current challenges. The article presents the concept of ST - its definition, components, history and applications - and describes its contribution to school management. It concludes by discussing practical processes including screening for ST-skilled principals and developing ST skills among prospective and current school principals, pinpointing three opportunities for skills acquisition: during preparatory programmes; during their first years on the job, supported by veteran school principals as mentors; and throughout their career.

As this is our final issue of 2013, I would like to acknowledge the vital support of our peer reviewers. For obvious reasons, we are precluded from mentioning them by name in each issue, but at minimal risk of compromising their anonymity, we would like to extend our gratitude and appreciation to the following individuals who reviewed articles in 2013:

Helen Abadzi, Washington DC (formerly World Bank)

Christel Adick, Ruhr University, Bochum

Abdeljalil Akkari, University of Geneva

Ali Sharaf Al Musawi, Sultan Qaboos University, Muscat

Panayiotis Antoniou, University of Cambridge

Marc Atallah, University of Lausanne

Zvi Bekerman, Hebrew University, Jerusalem

Stephanie Bengtsson, University of Newcastle, Australia

Anna Bernhardt, UNESCO Institute for Lifelong Learning, Hamburg

Sandra Bohlinger, University of Osnabrück

Madina Bolly, UNESCO Institute for Lifelong Learning, Hamburg

Alain Bouchard, Université Laval, Québec

Laurette Bristol, Charles Stute University, Bathurst

Birgit Brock-Utne, University of Oslo

Adrian Curaj, Executive Agency for Higher Education, Research, Development and Innovation Funding, Bucharest

David W. Chapman, University of Minnesota

Rachel Christina, International Development Division, Washington

Parfait M. Eloundou-Enyegue, Cornell University, Ithaka

Michael Fullan, University of Toronto

Charles Glenn, Boston University

César Guadalupe, Universidad del Pacífico, Lima

Ulrike Hanemann, UNESCO Institute for Lifelong Learning, Hamburg

Keith Hart, Goldsmiths, University of London

Ruth Hayhoe, University of Toronto 
Günter Hefler, 3S Research Laboratory, Vienna

Halla Holmarsdottir, Oslo and Akershus University College

Muir Houston, University of Glasgow

Heather Jacklin, University of Cape Town

Alisa Jones, Stanford University

Larisa Kasumagic, Sarajevo University

Marianne Larsen, University of Western Ontario, London (Canada)

Leslie Limage, International and Comparative Education Expert, Paris (formerly UNESCO)

Aïcha Maherzi, Université de Toulouse II

Hideki Maruyama, National Institute for Educational Policy Research, Tokyo

Alejandrina Mata-Segreda, Universidad de Costa Rica

Golnar Mehran, Al-Zahra University, Tehran

Kurt Meredith, University of Northern Iowa, Cedar Falls

Stanley Mpofu, National University of Science \& Technology, Bulawayo

Renate Nestvogel, University of Duisburg

Peter Scott, University of London

Adama Ouane, Independent Specialist in Education, Literacy and Language for

Development Mali (formerly UNESCO)

Angela Owusu-Boampong, UNESCO Institute for Lifelong Learning, Hamburg

Hilda Ana María Patiño Domínguez, Iberoamericana University, Mexico

Simona Popa, UNESCO International Bureau for Education, Geneva

Julia Preece, University of KwaZulu-Natal

Goli Rezai-Rashti, Perdue University, West Lafayette

Luc Robene, Université Bordeaux II

Alan Rogers, University of East Anglia, Norwich

Peter Roslander, UNESCO Institute for Lifelong Learning, Hamburg

Suad Sakalli Gumus, Mustafa Kemal University, Antakya

Yusuf Sayed, University of Sussex, Brighton

Ian Solomonides, Macquarie University, Sydney

Erik van Schooten, University of Amsterdam

Clara Inés Stramiello, Universidad Católica Argentina, Buenos Aires

Darko Štrajn, Educational Research Institute, Ljubljana

Nelly P. Stromquist, University of Maryland

Lazar Vlasceanu, University of Bucharest

Geoffrey Walford, University of Oxford

Pierre Walter, The University of British Columbia, Vancouver

Anke Walzebug, Technical University Dortmund

Clive Whitehead, The University of Western Australia, Perth

David Blake Willis, Fielding Graduate University, Santa Barbara

Mark Wyatt, University of Portsmouth

Joseph Zajda, Australian Catholic University, Melbourne

Tiedao Zhang, Beijing Academy of Educational Science 


\section{References}

Berliner, D. C. (2009). Poverty and potential: Out-of-school factors and school success. Boulder and Tempe: Education and the Public Interest Center (EPIC) \& Education Policy Research Unit (EPRU). Retrieved 26 Jan 2014 from http://epicpolicy.org/publication/poverty-and-potential.

Chan, K. W. (2013). China: Internal migration. In The Encyclopedia of Global Human Migration.

Mandela, N. (2003). Lighting your way to a better future. Speech delivered at the launch of Mindset Network. Planetarium, University of Witwatersrand, Johannesburg, South Africa, 16 July. Retrieved 7 Feb 2014 from http://db.nelsonmandela.org/speeches/pub_view.asp?pg=item\&ItemID=NMS909 \&txtstr=education\%20is\%20the\%20most\%20powerful.

UNESCO (United Nations Educational, Scientific and Cultural Organization). (2014). Teaching and learning: Achieving quality for all. EFA Global Monitoring Report 2013/4. Paris: UNESCO. 